\title{
The Influence of Instructional Syntax to Engage EFL Students in Online Learning Environment
}

\author{
Darmawansah $^{1}$, Setyabudi Indartono ${ }^{2}$ \\ Yogyakarta State University, Indonesia \\ e-mail: darmawansah.2018@student.uny.ac.id
}

\begin{abstract}
:
This paper aims to analyse the instructional syntax for an online learning environment in English language learning. The data collection used lesson plans in a Spain-based English Academy. The research method used Hemphill's engagement criteria to find the syntax characteristic in the lesson plans instructions. Also, the study analysed the factors of engagement during the learning session. The study revealed the frequencies of the instructional syntax used by EFL teachers and how these instructions engage the students. The lessons plans were coded to find the most syntax used and the engagement criteria. The result identified 'ask' is the most used syntax with $15.3 \%$ while inquiries method (38.9\%) was using the most in teaching students online. Moreover, the distribution item of engagement factors as EFL online teachers' focus group discussion shows how the engagement model can be used for English learners. This study will contribute as an expanding method of English language learning in an online setting widely.

Keywords: instructional syntax analysis, lesson plan, online learning, students engagement
\end{abstract}

\section{Introduction}

Teaching EFL students have been challenging for decades due to the lack of intentional use of English among them. These students are believed to have less engagement in class (Huang, Liu, Wang, Tsai, \& Lin, 2017; Yakın \& Erdil, 2012; Zheng \& Yu, 2018). One believed that EFL students' cognitive engagement was not extensive. Others sought that it depended on their learning strategies and pair performance. Whereas Yakın \& Erdil (2012) argue that their first language (L1) influence their self-efficacy to show communication performance. Theoretically, the students' engagement has various explanations (Alarcon, Edwards, \& Menke, 2011; Jang, Reeve, \& Deci, 2010; Shernoff, Csikszentmihalyi, Schneider, \& Shernoff, 2014). They assume that flow theory, a self-determination theory, and resources theory can describe students' engagement clearly. Thus, scholars less agreement on the theoretical perspective on engagement for students. Further empirical finding on EFL students' engagement indicates different outcomes of engagement, such as students' performance, effective educational practices, and student success. Hence advanced studies of EFL students' engagement are needed. 
Those different perspectives and empirical findings promote scholars to find out the better conceptual approach to explain the phenomenon of EFL students' engagement (Chen, Lambert, \& Guidry, 2010; Schmitz \& Skinner, 1993; Spinks Jr., 2012). They believe that web-based learning technology, teachers' support, and motivation in the classroom able to increase the students' engagement. However, in the case for students with low motivation will influence on the issues of deterioration of their motivation whereas other argue that causality between the use of learning technology and student engagement is needed to be explained. Accordingly, further studies are needed. The instructional syntax is believed to have better ways to explain the EFL student engagement (Czerkawski \& Lyman, 2016; Meskill, 2005). The instructional design guides instructors and instructional designers by synthesising current research literature on student engagement in online learning environments. It is also able to attenuates the effect of personal background on engagement, eliminating the effect of prior achievement. Therefore, the study aims to analyse the instructional syntax to increase EFL-students' engagement. That analysis could be experienced through syntax to make a more precise understanding of teacherstudent communication. This study is believed to generate a better theoretical explanation on the EFL students' engagement in an online learning environment and enrich the empirical findings on the EFL students' engagement.

Online instruction in an online learning environment has given the new opportunity for all learners around the globe to elevate their competencies in particular skills wanted. Many online learnings offer various types of courses which can be easily accessed by learners. It reports that online learning has been growing fast since the students believe this type of approach is mostly asynchronous and mimic a classroom-based approach (Paterson, 2019). Evidence also shows that online course activities can replace traditional course (Collins, Schuster, Ludlow, \& Duff, 2002). Moreover, those online instructions give newly prospective and more comprehensive to the teachers (Knapczyk \& Hew, 2007). These benefits are believed by Beattie et al. (2002) to counter significance issues in the conventional learning process. However, educational expertise should give caution to the educators that unsuccessful online learning will occur if the approaches as same as in the traditional coursework. The use of teaching media as same as in conventional learning process is still doubtful to engage the student in online learning. Some conventional teaching strategies such as lectures, presentation, and any oral teaching tradition are not recommended to use very often. Therefore, the conversational cycle between teacher and student is more reliable. The cycle can be concluded in the cycle of conversation such as ; (a) providing information, (b) clarifying expectations, and (c) giving feedbacks (Knapczyk \& Hew, 2007). The conventional teaching methods should be transformed to be more engaged toward the students. If the teachers apply those conventional methods as an altar in online learning, it will not ensure the expected interaction to take place (Corry, 2012).

The teachers should notice the lack of information, the developing activities, and the time limitation (Abaidoo \& Arkorful, 2015) because the space of online learning is not as vast as traditional learning. This statement was supported by other scholars who found other disadvantages towards the use of online learning (Akkoyunlu \& Soylu, 2006; Collins, 2002; Hameed, Badii, \& Cullen, 2008; Klein \& Ware, 2003). For example, teachers usually do engage the students by approaching students who in needs and comparing or evaluating several concepts into teaching lessons in the conventional learning process. While they argue the material development for online learning would give extra burden for teachers to design specific 
forms of collective materials. In contrast, teachers do not have much time to develop any strategical activities due to the time limit and to get an implicit array how far the students have reached the objectives (Berge, 2002). Thus, the essential element in creating an online learning environment which aims to engage students is designing instructional activities which align to the learning objectives. Furthermore, the most frequent reproach is the complete absentia of vital personal interaction between the teachers and students. Despite these contrary arguments, the lesson plans' syntax should perceive those instructional activities so that teachers may reduce those issues.

\section{Literature Review}

\subsection{Nature of EFL Student Engagement Learning}

The student engagement has been studying for decades by scholars in the educational context. The long history of student engagement mostly bring the academic relevance and the improvement of student achievement (Gettinger \& Seibert, 2002), yet some scholars define student engagement by linking to the academic task and activities which bring the critical factor of student success in the learning process. This multidimensional process are involving several aspects such as (a) student's emotion, (b) behaviour, and (c) cognition (Fredricks, Blumenfeld, \& Paris, 2004). Some empirical studies have been conducted by scholars to find the most suitable student engagement in the learning process (Carini, Kuh, \& Klein, 2006; Kuh, 2001; Skinner \& Belmont, 1993). While Carini et al. (2006) found there is a relationship between students engagement and academic performance, when the measurement went to the lowest ability students, Kuh (2001) stated that the student-teacher relationship is critical to examine the level of engagement.

In the EFL context, the teacher motivational strategies take the lead onto the behavioural value of the EFL student. Both aspects are relatively correlation between referring to how engagement might occur in the socio-educational learning (Papi \& Abdollahzadeh, 2012). Theories have been built to validate the substance of EFL student engagement (Dincer, Yesilyurt, \& Takkac, 2012; Han \& Hyland, 2015). A theory named self-determination theory divides the context of learning into two major groups (autonomy-supportive and teacher behaviour) which indicate teachers capacities in the EFL classrooms. Moreover, in the novelty of EFL learner engagement in the writing class, the written corrective feedback (WCF) has explored how EFL learner engages through cognitive, behaviour, and active engagement. Hence continuous research in practical engagement toward EFL students is needed to amplify the nature of learning engagement in terms of the student-teacher relationship.

\subsection{The Challenges of EFL Engagement for Online Learning}

The idea of delivering online learning may lead to some challenges in some particular levels of engagement. Pawan et al. (2003) argue that the online learning platform refers to the theory of social learning which EFL student understanding mostly comes through modelling, participating, and giving reaction to the behaviour in the learning process. Technology platform could nevertheless increase students' engagement in the EFL context. Previous research has shown how students tended to get positive response and attitude in the learning process (Al-Jarf, 2012) while another research adverted to the student's willingness in participating school routine is significantly raising (Harris, 2011). 
Shih et al. (2013) stated that the term of engagement infers to learners' satisfaction, which has been a substantial factor in online learning. This particular factor had been investigated for decades by many scholars (Arbaugh \& Duray, 2002; Artino, 2009; Biner, Dean, \& Mellinger, 1994; Driver, 2002; Muilenburg \& Berge, 2005; Osman \& Herring, 2007; Sun, Tsai, Finger, Chen, \& Yeh, 2008) in order to justify how satisfaction could lead to better engagement. The learners' satisfaction factor would be challenging to get an effective result if students find difficulties which caused by some factors such as lack of interaction, academic skills, access to the internet, and the occurrence of technical problems (Muilenburg \& Berge, 2005). Moreover, the student anxiety, the attitude of the teacher, and the diversity of instruction could lead another challenging towards online learning (Sun et al., 2008). A scholar explicitly stated the instructional interaction could contribute off the acceptance and the satisfaction in an online learning environment (Artino, 2009). However, they study to measure how the significance of every instruction that used during the online learning course is rarely to find in the current research. Therefore, this study brings a hypothesis to bring up the specific engagement style of EFL students for an online learning environment.

\subsection{The Role of Instructional Syntax}

The instructional syntax analysis has basic principles. These principles aim to classify the dealings of learners and the learning environment. The interactions include; reactive, proactive, and mutual (Schwier, 2009). The criteria enable the teachers to reckon the students' engagement throughout the online learning activities. In terms of evaluation instruction, the instructional syntax analysis is one approach to evaluate how the interaction between students and teachers in the online learning environment (Hemphill, 2000). It also may lead to new ways of evaluation instruction to understand the establishment of a genuine dialogue with the students.

Drawing proper instruction to the students will bring their attention to the form of words given. Bear et al. (2011) found when the young learners' study to spell some words in different forms such as of inform/information, paint/painting. This type of lesson aims to identify the part of speech, an essential objective in English learning, that associates with an introduction topic. Syntax relates to lexical. The high quality lexical in the lesson plan is carefully built to engage students. The instructional sequences in lesson plans also take an essential role to consider for the teacher. Those sequences begin to give attention to the student's interaction.

In the English learning environment, teachers should be capable of designing their instructional sequences. These sequences can assist in encountering their needs. One of the examples of instructional sequences in learning English vocabulary consists of a reflective introduction to the words set, exciting dealings with the words, and students knowledge assessment (Kucan, 2012). This particular sequence can be used with students at any proficiency level (Beck, McKeown, \& Kucan, 2002). The fact is that students need an instructional syntax that allows them to build their words or phrases for delivering into the conversation. That instruction can be not only incidental but also well-planned in teachers lesson plans. This plan will endure students' engagement in the online learning environment. Therefore, it is a fundamental factor to choose and to apply particular instructional syntax to increase student engagement in the online learning environment. It leads this study to bring another hypothesis to justify the clearer and more specific instructional syntax that can increase EFL students engagement for an online learning environment. 


\section{Research Methodology}

This study conducted an instructional syntax analysis for English online learning environment through lesson plans. There were 282 lesson plans designed for various levels of students. The lesson plans have been using since September 2018. The lesson plans designed by using the Cambridge ESOL curriculum which widely implements in Europe. This study was taken in an online English Academy based in Valladolid of Spain. Those lesson plans were coded then further analysed using descriptive statistic to identify the frequency of used instructional syntax, engagement criteria and learning theories through the lesson plan.

To understand the instructional syntax made by EFL teachers for teaching English in online learning. The lesson plans syntax was framed to the conceptual framework for methods of instruction in online learning. The next step was inviting five EFL online teachers to have a focus group discussion (FGD). It was an adjustment to discuss factors of engagement in an online learning environment, so the identification of typical students behaviours could be generally described (Handelsman, Briggs, Sullivan, \& Towler, 2005).

\section{Findings and Discussion}

The study's findings are presented for each question and revealed below;

Research question \#1: What are the clearer and more specific instructional syntax that can increase EFL students engagement for an online learning environment?

Table 1 reveals that teachers mostly use 'ask' in their lesson plan (15.3\%), the second and third most are 'open' (11\%) and 'show" (9.8\%). These syntaxes show more on the teachers' lesson plan due to the one-way direction and the use of visual tools (picture, powerpoint slides, video, and realia).

Table 1. Instructional Syntax

\begin{tabular}{lrrrr}
\hline & Frequency & Percent & Valid Percent & $\begin{array}{c}\text { Cumulative } \\
\text { Percent }\end{array}$ \\
\hline Ask & 175 & 15,3 & 15,3 & 15,3 \\
Choose & 1 &, 1 &, 1 & 15,4 \\
Confirm & 1 &, 1 &, 1 & 15,5 \\
Continue & 37 & 3,2 & 3,2 & 18,7 \\
Decide & 1 &, 1 &, 1 & 18,8 \\
Deliver & 8 &, 7 &, 7 & 19,5 \\
Describe & 23 & 2,0 & 2,0 & 21,5 \\
Discuss & 18 & 1,6 & 1,6 & 23,1 \\
Draw & 3 &, 3 &, 3 & 23,4 \\
Drill & 2 &, 2 &, 2 & 23,6 \\
Elaborate & 1 &, 1 &, 1 & 23,6 \\
Encourage & 36 & 3,2 & 3,2 & 26,8 \\
Explain & 41 & 3,6 & 3,6 & 30,4 \\
Give & 2 &, 2 &, 2 & 30,6 \\
Help & 7 &, 6 &, 6 & 31,2 \\
Hide & 14 & 1,2 & 1,2 & 32,4 \\
Inform & 8 &, 7 &, 7 & 33,1 \\
Introduce & 10 &, 9 &, 9 & 34,0 \\
Lead & 4 &, 4 &, 4 & 34,3 \\
\hline
\end{tabular}




\begin{tabular}{|c|c|c|c|c|}
\hline Let & 2 & ,2 & ,2 & 34,5 \\
\hline Make & 24 & 2,1 & 2,1 & 36,6 \\
\hline Mention & 12 & 1,1 & 1,1 & 37,7 \\
\hline Open & 126 & 11,0 & 11,0 & 48,7 \\
\hline Point & 17 & 1,5 & 1,5 & 50,2 \\
\hline Practice & 21 & 1,8 & 1,8 & 52,0 \\
\hline Prepare & 1 &, 1 &, 1 & 52,1 \\
\hline Remind & 16 & 1,4 & 1,4 & 53,5 \\
\hline Repeat & 15 & 1,3 & 1,3 & 54,8 \\
\hline Review & 12 & 1,1 & 1,1 & 55,9 \\
\hline Share & 3 & ,3 & ,3 & 56,1 \\
\hline Show & 112 & 9,8 & 9,8 & 65,9 \\
\hline Talk & 63 & 5,5 & 5,5 & 71,5 \\
\hline Teach & 52 & 4,6 & 4,6 & 76,0 \\
\hline Tell & 19 & 1,7 & 1,7 & 77,7 \\
\hline Try & 77 & 6,7 & 6,7 & 84,4 \\
\hline Write & 68 & 6,0 & 6,0 & 90,4 \\
\hline Read & 76 & 6,7 & 6,7 & 97,0 \\
\hline Find & 5 & ,4 &, 4 & 97,5 \\
\hline Use & 3 &, 3 &, 3 & 97,7 \\
\hline Accept & 1 &, 1 &, 1 & 97,8 \\
\hline Speak & 1 &, 1 &, 1 & 97,9 \\
\hline List & 1 & , 1 &, 1 & 98,0 \\
\hline Guess & 1 & , 1 &, 1 & 98,1 \\
\hline Learn & 1 & , 1 & , 1 & 98,2 \\
\hline Wait & 6 &, 5 &, 5 & 98,7 \\
\hline Check & 15 & 1,3 & 1,3 & 100,0 \\
\hline Total & 1142 & 100,0 & 100,0 & \\
\hline
\end{tabular}

\subsection{The Upbringing of Social Constructive in Online Learning}

This result brings a new perspective of an online learning environment that this phenomenon can be related to the application, either applicational or observational behaviours. The ideal engagement provides both application and observation behaviours to support the online environment. For example; the syntax "ask" is an example of application behaviour to observe the students respond, whereas "open" is a syntax which had numerous used by EFL teachers. It aimed to notice the student's behaviour when they were instructed. This idea fits with a constructive social perspective which notion may indicate students learning by reading, listening, and thinking. Scholars mostly agree on the validity of Vygotsky's idea (2006) about the learning social nature which can only be reached when there is a range of communication to test our skill and knowledge (Chen et al., 2010; Liu \& Matthews, 2005; Popkewitz, 1998; Woo \& Reeves, 2007). This interaction may occur with significant instructional syntaxes stated above. By using the proper instructional syntax, it can allow students to become more knowledgeable in the English language. Therefore, this social constructive by presenting proper instructional syntax is correlated with student's engagement in an online learning environment.

\subsection{Online Learning through Inquiry based-Instruction}

Another finding which can be discussed is the gap of students intentional use in online learning continues to be a lesser extent since both teacher and student experience of inquiry during the 
session. The result indicates the reliability of using inquiry in the learning instructions. Thus the finding shows the deep approaches of inquiry bring positive and logical attitude towards the student to face online learning environment. "Learning through inquiry" itself has been a comprehensive approach to help to boost students' knowledge and skills required (Land \& Hannafin, 2000). This term is mostly referred to many pedagogical approaches such as problembased learning and collaborative knowledge construction. Therefore, the teacher may be able to develop students' ability to formulate any learning objectives. The theoretical approach by giving inquiry was adopted by EFL online teachers would motivate often and desire to develop more engagement and constructive per se as well as develop the necessary cognitive strategies for the sake of active learning (Herrington \& Oliver, 2000; Loyens, Rikers, \& Schmidt, 2006).

The use of inquiry as part of the pedagogical approach is most relevant to the previous study which stated that particular syntax used in the online learning would bring better engagement to both parties (Meskill, 2005). The study interpretation based on the identification of syntaxes used by EFL online teachers and how that syntax reflects proactive behaviour and autonomous learning at some points. Even though there is no guarantee that only provision of using inquiry in the online learning process would directly link to quality learning outcomes, but the finding can bring evidence of active learning situational in this environment which is linked to the fewer dropout rates at the end of the program.

The understanding of study provided by using inquiry is salutary for EFL online teachers who spend significant effort to design proper lesson plans in order to construct new and innovative inquiry-based activities in the context of online learning. It is clearly stated how the integration between online learning and inquiry-based instruction. In the name of design learning, EFL online teachers are likely to be well worth of the effort if they spend more time to design useful stages of an online learning session. It may likewise find out the proper adjustment for the stronger sense of student' experience of learning English online.

Research question \#2: Do the EFL students have specific engagement style for an online learning environment?

Table 2 reveals that the most criteria engagement used by teachers is 'inquiries' (38.9\%). Further analysis revealed that inquiries criteria are related to the most instructional syntax (ask) used on the lesson plan. Simulation criteria also more contribute than other criteria (26.8\%). Also, explanation contributed $19.1 \%$ and followed by tips or course information (15.2\%)

Table 2. Engagement Criteria

\begin{tabular}{llrrrr}
\hline & Frequency & Percent & Valid Percent & \multicolumn{2}{c}{ Cumulative } \\
Percent
\end{tabular}

\subsection{Online learning engagement styles and criteria}

This number of criteria was somewhat surprising. The EFL teachers logged inquiry as an overall winning criterion to engage their students. It indicates how behaviour engagement was mostly 
observed during the learning session. Moreover, it is necessarily indicative of being engaged with the student responds by inquiry has brought the level of the successful learning process for EFL teachers. Finally, this engagement criteria had added another prosperous result in engaging learners who had been proven by other scholars (Carless, 2007; Charlton \& Danforth, 2004; Glasgow et al., 2007; Herrington, Oliver, \& Reeves, 2003; Ivankova, 2014; Roffe, 2002).

Charles (2007) addressed to emphasise inquiry as partial instruction of learning-oriented assessment. It was conceptually underpinning to emerge the learners' experience in any practical learning environment. To be compared, the instructional style to enlarge the engagement scale in online learning is an inquiry. Thus this reliability style of engagement brings kind of complex learning to which EFL online learners aspires. Simulation goes second largest to contribute the engagement criterion. Simulational instruction can lead to computing activities which are believed to create high engagement. In teaching EFL context, the high engagement is valued by measuring cognitive saliences and the appearance of tolerance between both parties. Charles and Danfort (2004) argue that some behaviours in surrounding computing may occupy the most abundant time of learners to get higher engagement. Although few perspectives consider it as goes to deteriorating learners lives, but EFL online learners are still a lead of session. Therefore the self-neglect attitude can be reduced. This idea was supported by Glasgow et al. (2007) who concluded the computing higher engagement might not link to the lack of individual retention and related to individuals characteristics themselves. To end, giving simulational instruction can initially continue online learning engagement in intervene students activities during their learning session.

The other patterns of engagement are explaining (19.2\%) and tips (15.2\%) to online learners. These scenarios have emerged the authentic tasks aspect in online learning environment. Reeves et al. (2003) explained how authentic activities could overcome a lack of attention during the learning process. The required activities can include students requirement to define the tasks and sub-tasks by completing lesson activity and the opportunity for students to reflect at the end of learning session. When EFL online teachers gave explanation and tips to the learners, the phrase of willing acceptance and relief from students could appear since the EFL online teachers represent themselves indecisive action, comfortably, and unambiguously. It would lead the proper parameter to increase engagement in online learning. However, it should be biggest concern if these attitudes are promoted to few students ages, particularly young learners who have issues by adapting computer-based learning. Therefore, it cannot be restricted to implement specific authentic learning activities in order to keep sustaining the acceptance of online learning environment (Roffe, 2002).

\subsection{The relationship between instructional syntax and engagement factors}

To ensure the validity of the study, a focus group of five EFL online teachers met to discuss and to identify what each of the four factors of engagement effects in online learning. Those factors discussed were skills engagement, participation engagement, emotional engagement, and performance engagement. To measure how the EFL teachers perspectives in engaging students through the online learning environment, this study adapted the online student's engagement scale (OSE) to complete the correlation between the instructional syntax and types of students engaged in the online learning environment (Dixson, 2015). The discussion among EFL online teachers result is shown below: 
Table 3. Item Distribution Across Factors of Engagement

\begin{tabular}{|c|c|c|c|}
\hline Skills & Emotion & Participation & Performance \\
\hline Apply proper English & Share daily activities & Ask questions & $\begin{array}{l}\text { Able to do extra } \\
\text { lesson/topic }\end{array}$ \\
\hline Listen/read carefully & Give feedback/comment & $\begin{array}{l}\text { Engage in the } \\
\text { discussion }\end{array}$ & $\begin{array}{l}\text { Get excellent } \\
\text { performance in } \\
\text { answering questions }\end{array}$ \\
\hline $\begin{array}{l}\text { Take notes over } \\
\text { slides have given, picture, etc }\end{array}$ & Put effort & $\begin{array}{l}\text { Get to know each } \\
\text { other }\end{array}$ & Do the homework \\
\hline Remember the previous lesson & Be happy in the session & & \\
\hline Describe pictures given & Be well-response & & \\
\hline
\end{tabular}

The table above served the reliable indicators of engaging students in the online learning environment. These factors of engagement came across activities which mostly found and done by EFL teachers. It contained the expectation from four factors: skills (i.e., applying proper English, listening the teacher carefully), emotion (i.e., sharing their activities, giving comments during the session), participation (i.e., asking questions, getting to know their EFL teacher), and performance (i.e., doing their homework). However, keep in mind that this result was EFL teachers' perceptions when they faced the pattern of engagement in an online learning environment. The finding that the application of engagement factors is significantly correlated with the active support of teachers behaviour during the online session. However, this finding is not being supported by taking students attitude. Thus social constructionist perspectives from students are not presented in this report. Despite the teacher's perceptions, this result is correlatively supported by other research (Herrington et al., 2003; Robinson \&Hullinger, 2008) that showed the willingly immerse of students to learn whereas given authentic activities and the use of selected key engagement dimensions to offer valuable experience in online learning. It might not be engaged enough by giving only instructions to the students such as reading the text, answering the question, and so on. So the number of instructions is supposed to differ in order to get relevant engagement between students and teachers as well.

The expected factors engagement is urgently required since the needs of interaction for online learning environment would fit to enhance student capacities to be active learners. In some cases, traditionally lecturing style in online learning is not as engaged as a conventional classroom. Ghani (2009) argues that emphasising on giving students rules to memorise does not significantly give better encouragement than practising active learning instead. Therefore, the study result can give various adjunct to the online learning practitioners for indicating the amount of students works before enacting typical behaviours, which demonstrate their learning engagement in the online environment.

\section{Conclusion}

This present study examines the instructional syntax that teachers use for English online learning environment in Spain-based English academy. It shows 46 instructions used on 282 lesson plans made by EFL online teachers. It revealed 'ask' as the most syntax used in online learning. It reflects how inquiries are widely accepted in teaching learners through online in terms of students' engagement. The simulation criteria also bring another approach in the English online learning environment. Roleplay and extended case discussion are examples of how simulation may engage students in online learning. Also, this study found learning activities 
in an online learning environment. The types of engagement are described to get potential future research on this topic. While the most syntax has found, this study also provided evidence that the criteria of online engagement are mostly inquiring the student so that further activities can be developed. Moreover, the FGD among EFL online teachers supported the result, then the primary purpose of this study was accomplished.

The implication of this study may impact on standardising the use of instructional syntax for EFL teachers when developing their teaching materials (i.e., lesson plan, supplementary materials). This study has brought evidence to the significant influence of proper instructional syntax in an online learning environment. If an individual or EFL teachers wished to give an exceptional experience to their online students, this individual or EFL teachers could modify their instruction by reflecting on this study's result in terms of increasing the student engagement by combining other media.

\section{References}

Abaidoo, V., \& Arkorful, N. (2015). The role of e-learning, advantages and disadvantages of its adoption in higher education. International Journal of Instructional Technology and Distance Learning, 2(12), 2014.

Akkoyunlu, B., \& Soylu, M. Y. (2006). A study on students' views on blended learning environment. Turkish Online Journal of Distance Education, 7(3).

Al-Jarf, R. (2012). Online Videos for Specific Purposes. Journal of Educational and Social Research, 2.

Alarcon, G. M., Edwards, J. M., \& Menke, L. E. (2011). Student burnout and engagement: A test of the conservation of resources theory. Journal of Psychology: Interdisciplinary and Applied, 145(3).

Arbaugh, J. B., \& Duray, R. (2002). Technological and Structural Characteristics, Student Learning and Satisfaction with Web-Based Courses. Management Learning, 33(3), 331-347.

Artino, A. R. (2009). Online learning: Are subjective perceptions of instructional context related to academic success? The Internet and Higher Education, 12(3-4), 117-125.

August, D., Bear, D.R., Dole, J.A., Echevarria, J., Fisher, D., F. et al. (2011). Treasures: A reading/language arts program. New York: Macmillan/McGraw-Hill.

Beattie, J., Spooner, F., Jordan, L., Algozzine, B., \&, \& Spooner, M. (2002). Evaluating instruction in distance learning classes. Teacher Education and Special Education, 25, 124-132.

Beck, I. L., McKeown, M. G., \& Kucan, L. (2002). Bringing words to life, robust vocabulary instruction. In Bringing words to life, robust vocabulary instrcution.

Berge, Z. L. (2002). Active, Interactive, and Reflective E-Learning. The Quarterly Review of Distance Education, 3(2).

Biner, P. M., Dean, R. S., \& Mellinger, A. E. (1994). Factors underlying distance learner satisfaction with televised college-level courses. American Journal of Distance Education, $8(1), 60-71$.

Carini, R. M., Kuh, G. D., \& Klein, S. P. (2006). Student Engagement and Student Learning: Testing the Linkages*. Research in Higher Education, 47(1), 1-32.

Carless, D. (2007). Learning-oriented assessment: conceptual bases and practical implications. Innovations in Education and Teaching International, 44(1), 57-66.

Charlton, J. P., \& Danforth, I. D. W. (2004). Differentiating computer-related addictions and high engagement. Human Perspectives in the Internet Society: Culture, Psychology and Gender, 31.

Chen, P.-S. D., Lambert, A. D., \& Guidry, K. R. (2010). Engaging online learners: The impact of Web-based learning technology on college student engagement. Computers \& Education, 54(4), 1222-1232.

Collins, B. C., Schuster, J. W., Ludlow, B. L., \& Duff, M. (2002). Planning and Delivery of Online Coursework in Special Education. Teacher Education and Special Education: The Journal of the Teacher Education Division of the Council for Exceptional Children, 25(2), 171-186. 
Collins, J. (2002). Teaching and Learning with Multimedia, Routledge: London.

Corry, M. (2012). Distance Education. In Distance Education: What Works Well.

Czerkawski, B. C., \& Lyman, E. W. (2016). An Instructional Design Framework for Fostering Student Engagement in Online Learning Environments. TechTrends, 60(6), 532-539.

Dincer, A., Yesilyurt, S., \&Takkac, M. (2012). The Effects of Autonomy-Supportive Climates on EFL Learner's Engagement, Achievement and Competence in English Speaking Classrooms. Procedia - Social and Behavioral Sciences, 46, 3890-3894.

Dixson, M. D. (2015). Measuring student engagement in the online course: The online student engagement scale (OSE). Journal of Asynchronous Learning Network, 19(4).

Driver, M. (2002). Exploring student perceptions of group interaction and class satisfaction in the web-enhanced classroom. The Internet and Higher Education, 5(1), 35-45.

Fredricks, J. A., Blumenfeld, P. C., \& Paris, A. H. (2004). School Engagement: Potential of the Concept, State of the Evidence. Review of Educational Research, 74(1), 59-109.

Gettinger, M., \& Seibert, J. K. (2002). Best Practices in Increasing Academic Learning Time. Best Practices in School Psychology, 4.

Ghani, S. A. (2009). Cooperative Learning Versus The Lecture Method of Instruction in An Introductory Statistics Course. Jurnal Sains Dan Matematik, 1(1), 59-71.

Glasgow, R. E., Nelson, C. C., Kearney, K. A., Reid, R., Ritzwoller, D. P., Strecher, V. J., ...Wildenhaus, K. (2007). Reach, Engagement, and Retention in an Internet-Based Weight Loss Program in a Multi-Site Randomized Controlled Trial. Journal of Medical Internet Research, 9(2), e11.

Hameed, S., Badii, A., \& Cullen, A. J. (2008). Effective e-learning integration with traditional learning in a blended learning environment. Proceedings of the European and Mediterranean Conference on Information Systems, EMCIS 2008, 25-26.

Han, Y., \& Hyland, F. (2015). Exploring learner engagement with written corrective feedback in a Chinese tertiary EFL classroom. Journal of Second Language Writing, 30, 31-44.

Handelsman, M. M., Briggs, W. L., Sullivan, N., \& Towler, A. (2005). A Measure of College Student Course Engagement. The Journal of Educational Research, 98(3), 184-192.

Harris, L. (2011). Secondary teachers' conceptions of student engagement: Engagement in learning or in schooling? Teaching and Teacher Education, 27(2), 376-386.

Hemphill, H. (2000). The language of instruction: Assessing the instructional syntax of technology-based training. Educational Technology, 40(4), 53-56.

Herrington, J., \& Oliver, R. (2000). An instructional design framework for authentic learning environments. Educational Technology Research and Development, 48(3), 23-48.

Herrington, J., Oliver, R., \& Reeves, T. C. (2003). Patterns of engagement in authentic online learning environments. Australasian Journal of Educational Technology, 19(1).

Huang, Y. Y., Liu, C. C., Wang, Y., Tsai, C. C., \& Lin, H. M. (2017). Student engagement in longterm collaborative EFL storytelling activities: An analysis of learners with english proficiency differences. Educational Technology and Society, 20(3), 95-109.

Ivankova, N.V. (2014). Implementing Quality Criteria in Designing and Conducting a Sequential QUAN $\rightarrow$ QUAL Mixed Methods Study of Student Engagement With Learning Applied Research Methods Online. Journal of Mixed Methods Research, 8(1), 25-51.

Jang, H., Reeve, J., \& Deci, E. L. (2010). Engaging students in learning activities: It is not autonomy support or structure but autonomy support and structure. Journal of Educational Psychology, 102(3), 588-600.

Klein, D., \& Ware, M. (2003). E-learning: new opportunities in continuing professional development. Learned Publishing, 16(1), 34-46.

Knapczyk, D. R., \& Hew, K. F. (2007). An Analysis and Evaluation of Online Instructional Activities. 30(3), 167-182.

Kucan, L. (2012). What Is Most Important to Know About Vocabulary? The Reading Teacher, 65(6), 360-366.

Kuh, G. D. (2001). Assessing What Really Matters to Student Learning Inside The National Survey of Student Engagement. Change: The Magazine of Higher Learning, 33(3), 10-17.

Land, S. M., \& Hannafin, M. J. (2000). Student-Centered Learning Environments. In Theoretical Foundations of Learning Environments.

Liu, C. H., \& Matthews, R. (2005). Vygotsky's philosophy: Constructivism and its criticisms examined. International Education Journal, 6(3), 386-399. 
Loyens, S. M. M., Rikers, R. M. J. P., \& Schmidt, H. G. (2006). Students' Conceptions of Constructivist Learning: A Comparison between a Traditional and a Problem-based Learning Curriculum. Advances in Health Sciences Education, 11(4), 365-379.

Meskill, C. (2005). Triadic scaffolds: Tools for teaching English language learners with computers. Language Learning \& Technology, 9(1), 46-59.

Muilenburg, L. Y., \& Berge, Z. L. (2005). Student barriers to online learning: A factor analytic study. Distance Education, 26(1), 29-48.

Osman, G., \& Herring, S. C. (2007). Interaction, facilitation, and deep learning in cross-cultural chat: A case study. The Internet and Higher Education, 10(2), 125-141.

Papi, M., \& Abdollahzadeh, E. (2012). Teacher Motivational Practice, Student Motivation, and Possible L2 Selves: An Examination in the Iranian EFL Context. Language Learning, 62(2), 571-594.

Paterson, J. (2019). Report: Online learning growth continues, but opportunities for improvement remain | Education Dive. Retrieved August23, 2019, from https://www.educationdive.com/news/report-online-learning-growth-continues-butopportunities-for-improvement/551403/

Pawan, F., Paulus, T. M., Yalcin, S., \& Chang, C. F. (2003). Online learning: Patterns of engagement and interaction among in-service teachers. Language Learning and Technology, $7(3), 119-140$.

Popkewitz, T. S. (1998). Dewey, Vygotsky, and the Social Administration of the Individual: Constructivist Pedagogy as Systems of Ideas in Historical Spaces. American Educational Research Journal, 35(4), 535-570.

Robinson, C. C., \& Hullinger, H. (2008). New Benchmarks in Higher Education: Student Engagement in Online Learning. Journal of Education for Business, 84(2), 101-109.

Roffe, I. (2002). E-learning: engagement, enhancement and execution. Quality Assurance in Education, 10(1), 40-50.

Schmitz, B., \&Skinner, E. (1993). Perceived control, effort, and academic performance: Interindividual, intraindividual, and multivariate time-series analyses. Journal of Personality and Social Psychology, 64(6), 1010-1028.

Schwier, R. A. (2009). Learning Environments and Interaction for Emerging Technologies: Implications for Learner Control and Practice. Canadian Journal of Learning and Technology / La Revue Canadienne de l'apprentissage et de La Technologie, 22(3).

Shernoff, D. J., Csikszentmihalyi, M., Schneider, B., \&Shernoff, E. S. (2014). Student Engagement in High School Classrooms from the Perspective of Flow Theory. In Applications of Flow in Human Development and Education (pp. 475-494).

Shih, H.-F., Chen, S.-H. E., Chen, S.-C., \& Wey, S.-C. (2013). The Relationship among Tertiary Level EFL Students' Personality, Online Learning Motivation and Online Learning Satisfaction. Procedia - Social and Behavioral Sciences, 103, 1152-1160.

Skinner, E. A., \& Belmont, M. J. (1993). Motivation in the classroom: Reciprocal effects of teacher behavior and student engagement across the school year. Journal of Educational Psychology, 85(4), 571-581.

Spinks Jr., J. D. (2012). Students' perception of engagement in a third-grade writing classroom.

Sun, P.-C., Tsai, R. J., Finger, G., Chen, Y.-Y., \& Yeh, D. (2008). What drives a successful eLearning? An empirical investigation of the critical factors influencing learner satisfaction. Computers \& Education, 50(4), 1183-1202.

Vygotsky, L. (2006). Thought and language. Cambridge, MA: The MIT Press.

Woo, Y., \& Reeves, T. C. (2007). Meaningful interaction in web-based learning: A social constructivist interpretation. The Internet and Higher Education, 10(1), 15-25.

Yakın, M., \& Erdil, O. (2012). Relationships Between Self-Efficacy and Work Engagement and the Effects on Job Satisfaction: A Survey on Certified Public Accountants. Procedia - Social and Behavioral Sciences, 58, 370-378.

Zheng, Y., \& Yu, S. (2018). Student engagement with teacher written corrective feedback in EFL writing: A case study of Chinese lower-proficiency students. Assessing Writing, 37, 13-24. 